Komunike, Volume XI, No. 2, Desember 2019

\title{
PENETRASI SOSIAL HUBUNGAN ANTAR BUDAYA WARGA RUMAH SUSUN (Study Komunikasi Interpersonal di Mandalika, Kota Mataram)
}

\author{
Muahammad Fathoni, Sri Devi Wahyuni \\ Universitas Islam Negeri Mataram \\ ujungtinta@gmail.com
}

\begin{abstract}
Abstrak
Penelitian ini menjelaskan tentang bagaimana proses komunikasi antarbudaya yang terjalin antar penghuni rusunawa Mandalika di lingkungan Montong Are secara interpersonal. Serta bagaimana faktorfaktor yang mempengaruhi perilaku komunikasi dalam kerukunan penghuni. Penelitian ini menggunakan metode fenomenologi untuk mengurai dan mendeskripsikan bagaimana perilaku dan proses komunikasi antarbudaya dalam kerukunan penghuni rumah susun warga di lingkungan Montong Are dalam sudut pandang pengalaman komunikasi penghuninya. Tekhnik pengumpulan data dalam penelitian ini menggunakan observasi,wawancaradan dokumentasi. Proses pengumpulan data dengan tekhnik snowball sampling/chain sampling sebanyak 10 orang informan. Hasil penelitian yang ditemukan perkembangan hubungan kerukunan di rusunawa Mandalika dipengaruhi oleh perilaku komunikasi antarbudaya masing-masing penghuninya secara interpersonal melalui tahapan personality structure dalam bentuk memahami konsep diri sebagai penghuni.Kedua yaitu closnessself disclosure dalam bentuk keterbukaan antar sesama. Ketiga yaitu the depth and breadth of self-disclosure dalam bentuk pemahaman, dan keempat ialah regulating closeness dalam bentuk kepercayaan antar sesame penghuni. Faktor yang mempengaruhi kerukunan perilaku komunikasi antarbudaya terhadap penghuni rusunawa Mandalika ialah para penghuni memiliki rasa kekerabatan dan kekeluargaan terhadap sesama dan solidaritas tinggi, juga terbiasa akan heterogenitas budaya satu sama lain sehingga terciptanya komunikasi yang efektif.
\end{abstract}

Kata kunci : Penetrasi sosial, Komunikasi, Antarbudaya, Kerukunan, Penghuni, Rusunawa. 
Komunike, Volume XI, No. 1, Juni 2019

\section{A. Pendahuluan}

Sebagai makhluk sosial, manusia telah dibekali dengan potensi untuk saling berkomunikasi. Komunikasi adalah proses berbagi makna melalui perilaku verbal dan nonverbal. ${ }^{1}$ Mengapa kita perlu berkomunikasi?Dari perspektif agama, secara agama kita bisa menjawab bahwa Tuhan-lah yang mengajari kita berkomunikasi, dengan menggunakan akal dan kemampuan berbahasa yang di anugerahkan-Nya kepada kita. Al-Qur'an mengatakan, "Tuhan yang maha pemurah, yang telah mengajarkan al-Qur'an. Dia menciptakan manusia, yang mengajarinya pandai berbicara" (ArRahman : 1-4). ${ }^{2}$

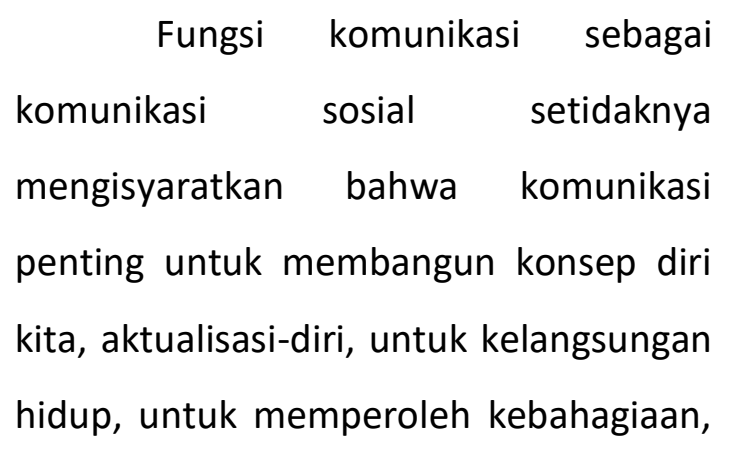

1 Deddy Mulyana, Komunikasi Efektif Suatu Pendekatan Lintas Budaya, (Bandung: PT. Remaja Rosdakayra, 2008), hlm. 3.

${ }^{2}$ Deddy Mulyana, IImu Komunikasi Suatu Pengantar, (Bandung: PT. Remaja Rosdakayra, 2008), hIm. 3 terhindar dari tekanan dan ketegangan, antara lain lewat komunikasi yang menghibur dan memupuk hubungan dengan orang lain. Melalui komunikasi kita bekerja sama dengan anggota masyarakat (keluarga, kelompok belajar, perguruan tinggi, RT, RW, desa, kota, dan Negara secara keseluruhan) untuk mencapai tujuan bersama. ${ }^{3}$

Hubungan antar sosio-budaya sangat erat kaitannya dalam konteks komunikasi. Dengan terjalinnya komunikasi antar sesama, lambat laun akan terbentuk sebuah kerukunan dengan saling mengenal perilaku masing-masing. Memiliki latar belakangan yang berbeda akan tetapi dapat terbentuk dengan mudah dengan adanya sistem komunikasi yang selalu terjalin dengan baik dan rukun. Itulah yang menyebabkan terciptanya keharmonisan dan kerukunan dalam suatu lingkup masyarakat setempat.

Rumah susun adalah bangunan yang digunakan untuk menampung sekumpulan manusia yang terorganisir kedalam suatu wadah dengan

\footnotetext{
${ }^{3}$ Ibid. hlm. 5-6.
} 
Komunike, Volume XI, No. 2, Desember 2019

pertimbangan kehidupan manusia hidup secara layak secara horizontal dan secara vertical dengan sistem pengelolaan yang menganut konsep kebersamaan. ${ }^{4}$

\section{Rumah Susun Warga} (Rusunawa) di Lingkungan Montong Are Tidak hanya dihuni oleh masyarakat Montong Are akan tetapi dari berbagai macam lingkungan di kota Mataram dan luar daerah yang ikut serta berdomisili ke Rusunawa. Karena menurut masyarakat selain fasilitas yang cukup memadai, juga terjangkau sangat murah.

\section{Perbedaan pada dasaranya} menjadi sumber masalah dan perpecahan dalam sebuah hubungan sosial di masarakat, akan tetapi perbedaan latar belakang masyarakat setempat tidak menjadikan sebuah alasan untuk menutup diri dari individu, kelompok maupun lingkungannya untuk saling bersosialisai, saling bertukar informasi. Justru sebagian masyarakat berinisiatif untuk selalu bersifat terbuka

\footnotetext{
${ }^{4}$ https://sites.google.com/site/arkideapr operty/input/info-rumah-susun/pengertianrumah-susun, diakses pada 10 januari 2019 pukul 20.26 .
}

satu sama lain. Bahkan sejauh ini dengan ke-latarbelakangan antarbudaya yang berbeda di banding konflik, penghuni rusunawa lebih condong hidup secara damai dan harmonis tidak seperti biasanya terjadi yang rentan oleh konflik karena memiliki latar belakang budaya yang berbeda.

Sehingga dari sana, Bagaimana perkembangan hubungan (penetrasi sosial) mereka bisa terjalin damai sehingga mereka bisa terlihat rukun dan harmonis di tengah-tengah perbedaan latar belakang budaya, dilihat dari komunikasi interpersonal penghuni Rusunawa yang berbeda budaya dan faktor-faktor yang mempengaruhi perilaku komunikasi antarbudaya terhadap kerukunan penghun I rusunawa dalam perbedaan latar belakang budaya di lingkungan Montong Are.

\section{B. METODE}

Pendekatan dalam penelitian ini menggunakan pendekatan fenomenologi. Dimana pendekatan fenomenologi merupakan pendekatan yang mencoba menjelaskan atau 
Komunike, Volume XI, No. 1, Juni 2019

mengungkapkan makna konsep atau <theoretical attitude,>the concepts "true fenomena pengalaman yang didasari being", "actual being," that is, real being oleh kesadaran yang terjadi pada and-since everything real joins together beberapa individu. Penelitian ini to make up the unity of the world dilakukan dalam situasi yang alami, "being in the world" coincide."

sehingga tidak ada batasan dalam Sampel dalam penelitian ini memaknai atau memahami fenomena menggunakan Snowball sampling yang dikaji. ${ }^{5}$

dijelaskan oleh Mc. Patton dalam

Pemilihan fenomenologi sebagai Fathoni sebagaiberikut: "chain sampling metode penelitian dikarenakan (snowballsampling). This is an approach permasalahan yang diteliti merupakan for locating information-rich key fenomena yang melibatkan pengalaman informants or critical cases.... Those kerukunan penghuni rusunanwa di people or events recommended as Montong Are, hal ini sesuai dengan valuable by a number of different pendapat Hussrel :"Natural cognition informants take on special importance. begins with experience and remains The chain of recommended informants within experience. In the theoretical will typi-cally diverge initially as many attitude which we call the "natural" possible sources are recommended, then (theoretical attitudefl the collective converge as a few key names get horizon of possible investigations is mentioned over and over"6. therefore designated with one word: It is Fathoni menambahkan Snowball/ the world). Accordingly, the sciences of chain sampling ini digunakan untuk this original attitude are, in their fenomena yang memiliki banyak sumber entirety, sciences of the world; and, as (informan) sehingga inforamasi yang long as it is the exclusively dominant didapatkan kaya akan data, kekayaan

\footnotetext{
${ }^{5}$ Juliansyah Noor, Metodologi Penelitian, (Jakarta: Kencana Prenada Media Group, 2011), hlm. 36.
}

${ }^{6}$ Muhammad Fathoni, Integrasi Muslim Dan Hindu Dalam Upacara Pujawali Dan Perang Topat: Studi Komunikasi Antar Budaya di Lingsar Lombok Barat, Thesis, (Surakarta: Universitas Sebelas Maret, 2016), h. 41-42. 
Komunike, Volume XI, No. 2, Desember 2019

data memungkinkan terjadinya ambiguitas dan ketidak konsistenan pada data yang akan sajikan (displaydata). sehingga perlu adanya chain atau rantai data yang sesuai antar informan untuk memperkuatnya dan mengkonsitensikannya. ${ }^{7}$

\section{Hasil dan Pembahasan Pembahasan}

1. Penetrasi soasial dalam komunikasi Penghuni Rusunawa Mandalika

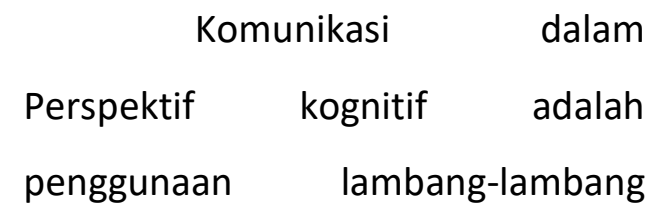

(symbol) untuk mencapai kesamaan

makna atau berbagi informasi

tentang satu objek atau kejadian.

Informasi adalah sesuatu (fakta,

opini, gagasan) dari satu partisipan

kepada partisipan lain. ${ }^{8}$

Komunikasi antarbudaya
yang terjalin antar penghuni

rusunawa sesuai dengan kebutuhan

komunikator akan berinteraksi dan

berkomunikasi dengan siapa dan

\footnotetext{
${ }^{7}$ Ibbid, h. 42.

${ }^{8}$ Burhan Pungin, Sosiologi Komunikasi: Teori, Paradigm dan Diskursus Teknologi Komunikasi Di Masyarakat, (Jakarta: PT Kencana Prenada Media Group 2007), hlm 254.
}

tujuan apa. Komunikasi yang sering terjalin ialah interpersonal ketika penghuni berbincang-bincang dengan para penghuni lainnya mengenai pendidikan, ekonomi, masalah sosial maupun sampai curhat dan lainnya. Adapun sebagaimana perilaku komunikasi antarbudaya yang terjalin dalam kerukunan penghuni rusunawa Mandalikaberlangsung baik hingga saat ini. Dengan demikian perilaku komunikasi yang terjalin baik menciptakan hubungan yang rukun antar sesama penghuni dan juga staf karyawan rusunawa baik secara individu maupun kelompok.

Joseph A. Devito, mengungkapkan bahwa komunikasi interpersonal yaitu proses pengiriman pesan-pesan antara dua orang atau sekelompok kecil orang dengan beberapa efek dan beberapa umpan balik seketika (the process of sending messages between two persons, or among a small group of person, with some effects and some immediate 
Komunike, Volume XI, No. 1, Juni 2019

feedback). ${ }^{9}$ Hal ini terlihat dalam perilaku penghuni rusunawa Mandalika yang ketika melakukan interaksi dengan penghuni lainnya ,. Penghuni atau komunikator menyampaikan serta menjelaskan pesannya kepada penghuni lainnya yang sebagai komunikan saling merespon satu sama lain.

\section{Komunikasi yang terjalin} antar penghuni rusunawa dibangun melalui suatu proses interaksi yang pleksibel. Mereka berkomunikasi sesuai dengan bahasa yang digunakan oleh lawan bicara atau komunikator, ketika menggunakan bahasa sasak maka komunikan akan merespon dengan bahasa sasak, begitupun sebaliknya. Hal tersebut dilakuakan agar tercapainya komunikasi yang di inginkan. Namun secara umum kecenderungan menggunakan bahasa Indonesia. Dari proses perilaku komunikasi yang terjalin diatas, hal ini dapat dikatakan sebagai aplikasi dari teori

${ }^{9}$ Nurani Soyomukti, Pengantar IImu Komunikasi, hlm. 142-143. penetrasi sosial. Dalam teori penetrasi sosial dijelaskan bahwa berkembangnya hubunganhubungan itu bergerak dari tingkatan yang paling dangkal, mulai dari tingkatan yang bukan bersifat inti menuju ke tingkatan yang terdalam, atau ke tingkatan yang lebih bersifat pribadi.

Semua orang memiliki jenis relasi tertentu dengan seseorang. Seseorang menjadi orang asing, lalu berkenalan atau berkawan, tergantung pada kebutuhan dan situasi. Irwin Altman dan Dalmas Taylor mengemukakan teori penetrasi sosial (SPT) di awal 1970an. ${ }^{10}$ berlangsung dalam empat tahapan :

a) Personality Structure: A Multilayered Onion

Altman and Taylor compare people to onions. "This isn't commentary on the human capacity to offend. Like the self-description that the ogre in Sherk shares with

${ }^{10}$ Stephen W. Littlejhon dan Karen A. Foss, Ensiklopedia Teori Komunikas Jilid 2, hal. 1096. 
Komunike, Volume XI, No. 2, Desember 2019

his donkey sidekick in the original film, it is description of the multilayered structure of personality". ${ }^{11}$

Sesuai dengan pernyataan Altman dan Taylor diatas dalam perkembangan sebuah hubungan diibaratkan seperti lapisan kulit bawang merah. Dengan analogi tersebut, maka dijelaskan bagaimana orang/penghuni rusunawa melalui interaksi saling mengelupasi lapisan-lapisan informasi mengenai diri masingmasing. Pada lapisan pertama atau terluar kulit bawang (tahap pertama), informasinya bersifat superficial. Informasi yang demikian wujudnya antara lain seperti informasi tentang nama, alamat, umur, suku dan lain sejenisnya. Seperti yang dikatakan oleh bapak kepala lingkungan Montong Are Abdul Hanan bahwa, mayoritas penduduk penghuni rusunawa

${ }^{11} \mathrm{EM}$ Griffin, A First Look At Communication Theory Eighth Edition, (Library Of Congress Cataloging-In-Publication Data), hlm. 114.
Mandalika berasal dari daerah yang berbeda-beda sehingga disana mereka akan melewati tahapan dari bertukarnya informasi secara umum untuk saling mengenal satu sama lain. Berawal dari mengetahui nama masing-masing, alamat yang ditempatkan sebelumnya atau dari daerah mana berasal, suku ras dan kepercayaan apa yang dianut dan dipegang berdasarkan keyakinan. Ketika setiap ada penghuni baru rusunawa Mandalika yang pindah dari asalnya dan menetap disini, para penghuni lama akan melakukan sebuah sambutan kepadanya dalam bentuk komunikasi ringan, menanyakan hal serupa yang bersifat umum dari nama, alamat dan sejenisnya. ${ }^{12}$ Informasi-informasi tersebut mengalir saat mereka berkomunikasi dengan orang yang baru di kenal. Begitu juga yang dilakukan oleh para penghuni baru rusunawa Mandalika ketika

\footnotetext{
12 Wawancara kepala UPTD rusunawa Mandalika bapak Zuhry, Montong Are Tanggal 23 Januari 2018
} 
Komunike, Volume XI, No. 1, Juni 2019

pertama kali tinggal disana, hal pertama yang dilakukan mereka ialah menanyakan hal-hal yang bersifat umum untuk menjalin hubungan dengan penghuni lama atau yang disebut dengan tahapan orientasi.

\section{Dengan tahap orientasi ini} memberikan peluang diperolehnya informasi-informasi baru tentang komunikator yang belum dikenal, yang nantinya informasi baru tersebut digunakan untuk saling memahami dalam proses pembentukan hubungan.

Hal tersebut juga digunakan untuk meredam ketidakpastian komunikasi yang dilakukan oleh komunikan dan komunikator yang dapat mengefektifkan komunikasi mereaka sehingga memberikan peluang terhubungnya ikatan baru diantara mereka.

b) Closeness Through Self-Disclosure

The depth of penetration represents the degree of personal disclosure. To get to the center, the wedge must first separate the outer layers. Altman and Taylor claim that on the surface level this kind of biographical information exchange takes palce easily, perhaps at the first meeting. ${ }^{13}$

Pada tahap kedua ini disebut dengan tahap pertukaran afektif eksploratif, tahap ekspansi awal dari informasi dan perpindahan ke tingkat pengungkapan yang lebih dalam dari tahap pertama. Dalam tahapan tersebut, diantara penghuni rusunawa satu dengan lainnya, dua orang atau lebih yang berkomunikasi mulai mengeksplorasi informasi yang berupaya menanyakan apa kesenangan masing-masing. Misalnya kesenangan dari segi makanan, musik, lagu, hobi, dan lain sejenisnya.

Penghuni rusunawa seringkali berkumpul melakukan komunikasi interpersonal untuk membicarakan kegemaran masingmasing (hobi) atau hal apa yang

\footnotetext{
${ }^{13} / \mathrm{bid}, \mathrm{hlm} .114$.
} 
Komunike, Volume XI, No. 2, Desember 2019

disukai dan tidak disukai. Sehingga dari tiap percakapan-percakapan yang dilewati memberikan informasi yang lebih mendalam terhadap komunikator. Tidah hanya itu sampai pada tahap yang lebih dalam dari sebelumnya seperti saling bertukar makanan, lauk pauk dan kue sesuai kebutuhan masingmasing.

Hal tersebut menandakan bahwa adanya keterbukaan dari penghuni rusunawa kepada yang lainya. Keterbukaan informasi meniscayakan adanya sebuah rasa keakraban yang ditandai dengan adanya komunikasi yang lancar dan efektif dalam bertukar informasi tanpa ada rasa kecanggungan diantara mereka.

c) The Depth and Breadth Of SelfDisclosure

The depth of penetration is the degree of intimacy. Although Altman and Taylor's penetration analogy strikes some readers as sexual, this was not their intent. ${ }^{14}$

Tahapan berikutnya adalah tahap ke tiga yaitu tahap pertukaran afektif. Pada tahap ini terjadi peningkatan informasi yang lebih bersifat pribadi, misalnya tentang informasi menyangkut pengalamanpengalaman privasi masing-masing. Dalam tahap ini warga penghuni rusunawa masing-masing sudah mulai membuka diri dengan informasi diri sendiri yang sifatnya lebih pribadi. seperti menceritakan tentang problem pribadi "curhat".

"Curhat" merupakan solusi dari permasalahan inti sebuah kehidupan. Kerapkali dilakukan oleh setiap individu-individu (warga rusunawa) untuk bertukar informasi, menyampaikan pesan antar komunikator dengan komunikan secara mendalam.

$$
\text { Disamping itu, Penghuni }
$$

rusunawa kerapkali melakukan komunikasi secara intens dan

\footnotetext{
${ }^{14}$ Ibid, hlm. 115.
} 
Komunike, Volume XI, No. 1, Juni 2019

mendalam (curhat) kepada penghuni lain yang telah dikenal lebih dekat dan merasa nyaman untuk mengekspresikan masalahmasalah yang dihadapi, sekaligus meminta saran sebagai solusi dalam menanggapi situasi yang terjadi dari inti problematika yang dialami.

Pada tahapan ke tiga ini masuk kedalam taraf pemahaman dan pengertian, ikatan kebersamaan yang tumbuh diantara mereka sehingga tumbuh rasa saling memahami dan mengayomi antar sesama warga rusunawa yang menjadi indikator tidak adanya sekat komunikasi diantara mereka.

Karena kedalaman ikatan merupakan hal penting dalam hubungan penetrasi sosial untuk pengembangan keakraban individuindividu maupun kelompok. membentuk komunitas bersama yang warga didalamya merasa menjadi bagian dari yang lain.

d) Regulating Closeness On The Basic Of Rewards and Costs
According to social penetration theory, it all depends on the cost-benefit analysis that each man performs as he considers the possibility of a closer relathionship. ${ }^{15}$ Yang terakhir adalah lapisan inti ke empat yaitu disebut juga dengan pertukaran yang stabil. Pada tahap tersebut sifatnya sudah sangan sangat intim dan memungkinkan warga penghuni rusunawa tersebut untuk memprediksikan tindakan-tindakan dan respon mereka masing-masing dengan baik. Informasi yang dibicarakan sudah sangat dalam dan menjadi inti dari pribadi masingmasing, misalnya soal nilai, konsep diri, atau perasaan emosi terdalam.

Sama halnya yang dilakukan oleh penghuni rusunawa Mandalika, membicarakan hal yang ringan hingga sampai ke titik saling curhat bertukar informasi mendalam mengenai suatu permasalahan masing-masing. Sehingga bagaimana antara tindakan

\footnotetext{
${ }^{15}$ Ibid, hlm. 117.
} 
Komunike, Volume XI, No. 2, Desember 2019

penghuni satu dengan lainnya sudah saling mengenal lebih dalam.

Pada tahapan yang terakhir ini, tidak ada lagi pembahasan mendasar tentang hal-hal yang terjadi pada lapisan-lapisan sebelumnya melainkan penerapan menjalin hubungan-hubungan yang tadi secara biasa dalam kehidupan sehari-hari mereka.

Hal ini terlihat dalam tolerasin antar warga rusunawa pada saat melakukan ritual keagamaan, setiap acara-acara keagamaan di rusunawa Mandalika. Warga Hindhu yang melakukan nyepi di rusunawa dan ketika warga Muslim acara Yasinan para penghuni tidak saling mengganggu, bahkan saling menjaga dan membantu agar kondisi tetap tenang dan kondusif selama peribadatan.

Hal ini tersebut menandakan adanya keintiman antar warga penghuni rusunawa, ditandai dengan saling menghargai dan saling membantunya antar warga yang bebeda keyakianan dalam proses komunikasi. Pada dasarnya kepercayaan dan keyakinan yang dianut merupakan hal yang sangat pribadi, akan tetapi mereka sangat terbuka akan hal tersebut dan mau berdamai dengan kondisi-kondisi yang melibatkan dengan kepercayaan masing-masing penghuni. Hal tersebut merupakan cerminan bahwa kearaban dan keintiman diantara mereka sudah sangat dalam dan stabil sehingga perbedaan keyakinan tidak menjadi sekat diantara mereka.

\section{Faktor-Faktor Yang Mempengaruhi Kerukunan dalam Komunikasi Antar Penghuni Rusunawa Mandalika}

Hubungan antara budaya dan komunikasi penting dipahami untuk memahami komunikasi antarbudaya, oleh karena melalui pengaruh budayalah orang-orang belajar berkomunikasi. ${ }^{16}$

Hubungan penghuni rusunawa Mandalika dengan penghuni lainnya

\footnotetext{
${ }^{16}$ Deddy Mulyana dan Jalaluddin Rakhmat, Komunikasi Antarbudaya (Panduan Berkomunikasi Dengan Orang-Orang Yang Berbeda Budaya), hlm. 24.
} 
Komunike, Volume XI, No. 1, Juni 2019

berjalan baik, hal tersebut dapat terlihat dari perilaku mereka seharihari dalam melakukan aktivitas maupun kegiatannya berinteraksi dan berkomunikasi satu dengan lainnya baik secara individu maupun kelompok. Hal tersebut dilakukan oleh para penghuni maupun staf-staf rusunawa lainnya dengan hubungan yang terjalin rukun antar sesama. faktor-faktor yang mempengaruhi kerukunan penghuni rusunawa Mandalika antara lain:

1. Kekerabatan dan Kekeluargaan Widianto, B., \& Halida, R. (2008) bahwa keluarga adalah kelanjutan dari pernikahan yang memiliki ikatan internal dan eksternal, ikatan kecil dan besar. ${ }^{17}$ Warga yang telah lama tinggal bersama-sama dalam rumah susun Mandalika di Montong Are memliki kedekatan dan anggapan saling memiliki dan mersakan kedekatan sebagai keluarga

17 Meinarno, E. A., Widianto, Manusia Dalam Kebudayaan Dan Masyarakat, (Jakarta: PT. Salemba Humanika, 2008), hlm. 25 secara tidak langsung dengan perilaku mereka sehari-hari.

Hal tersebut tercermin melalui saling membantu ketika ada kesulitan maupun musibah, ataupun berbagi makanan lauk pauk dengan penghuni lainya. Hal tersebut dilakukan penghuni rusunawa guna menjaga silaturrahmi mereka yang terjalin baik.

Dari pola prilaku tersebut muncul sikap saling mengayomi antar sesama meskipun ikatan seperti kekekerabatan terjalin dengan sendirinya tanpa disadari oleh penghuni rusunawa Mandalika yang berbeda suku budaya

Heterogenitas

Penghuni rusunawa Mandalika telah hidup berlangsung lama dalam perbedaan antar penghuni satu dengan lainnya. Kehidupan yang berlangsung dengan berbagai keadaan ekonomi, sosial dan budaya yang berbeda. Seperti yang dikatakan oleh ketua UPTD rusunawa Mandalika, orang-orang yang datang dari lokasi, budaya, agama suku dan ras yang berbeda berkumpul menjadi satu 
Komunike, Volume XI, No. 2, Desember 2019

lingkup dalam lingkungan yang sama kadang tidak mudah untuk menyatukan pikiran masing-masing. Akan tetapi diluar itu, para penghuni rusunawa Mandalika telah terbiasa dengan heterogenitas antar suku, ras atau agama maupun budaya lainnya yang menyebabkan mereka rukun dan tidak mempermasalahkan itu semua.

Perbedaan memberikan informasi kepada para warga penghuni rusunawa untuk bersikap kepada penghuni yang lainnya, pengambilan keputusan dalam mengambil tindakan menjadi lebih hati-hati dan mementingkan moral yang baik ketika dihadapkan pada perbedaan budaya. Sehingga dengan adanya heterogen membantu komunikator dan warga rusunawa untuk mengembangkan dan menerapkan kebiasan berkomuniaksi dengan cara-cara yang arip dan bijaksana.

3. Solidaritas yang tinggi

Solidaritas merupakan perasaan senasib atau setiakawan yang mengikat hubungan dalam masyarakat secara kolektif. Solidaritas antar penghuni rusunawa Mandalika terlihat dari perilaku mereka. Ketika salah seorang penghuni yang sakit dan harus segera dibawa ke rumah sakit, penghuni lainnya berkerjasama dan bahu-membahu menolong segera dan mengurus keluarga korban tanpa harus dimintai bantuan terlebih dahulu.

Sikap kerjasama dengan orang lain dapat mungkin terjadi jika masingmasing pihak dari warga rusunawa sadar bawa mereka punya kepentingan yang sama disaat yang besamaan, mereka memiliki pengetahuan dan pengendalian diri yang cukup untuk mencapai kepentingan tersebeut dengan solidaritas.

Sikap solidaritas ini juga menunjukkan bahwa etnosentrisme yang rendah antar penghuni rusunawa Mandalika sehingga sikap individualisme tidak berkembang diantara mereka. Inilah yang menyebabkan terjalin dan terjaganya sikap toleransi dan hubungan baik diantra warga rusunawa Mandalika Mataram. 
Komunike, Volume XI, No. 1, Juni 2019

\section{Kesimpulan}

1. kerukunan di rusunawa Mandalika dipengaruhi oleh perilaku komunikasi antarbudaya masing-masing penghuninya baik secara intrapersonal, interpersonal dan kelompok yaitu pertama melalui tahapan personality structure dalam bentuk memahami konsep diri sebagai penghuni. Kedua yaitu closness self disclosure dalam bentuk keterbukaan antar sesama. Ketiga yaitu the depth and breadth of selfdisclosure dalam bentuk pemahaman, dan keempat ialah regulating closeness dalam bentuk kepercayaan antar sesama penghuni.

2. Faktor-faktor yang mempengaruhi perilaku komunikasi antarbudaya terhadap kerukunan penghuni rusunawa Mandalika dalam perbedaan latar belakang budaya di lingkungan Montong Are yaitu: Kekerabatan dan kekeluargaan, Kebiasaan dalam heterogenitas budaya dan Solidaritas yang tinggi.

\section{DAFTAR PUSTAKA}

Effendi, Onong Uchjana, "Ilmu, Teori Dan Filsafat Komunikasi”Bandung: PT. Citra Aditya Bakti, 2007.

Fathoni, Muhammad. "Integrasi Muslim Dan Hindu Dalam Upacara Pujawali Dan Perang Topat: Studi Komunikasi Antar Budaya di Lingsar Lombok Barat, Thesis" Surakarta: Universitas Sebelas Maret, 2016.

Griffin, EM. A First Look At Communication Theory Eighth Edition, Library of Congress Cataloging-In-Publication, 2007.

Liliweri, Alo. Dasar-Dasar Komunikasi Antarbuday.Yogyakarta: Pustaka Pelajar, 2007.

Mulyana, Deddy dan Rahmat Jalaludin.Komunikasi Antarbudaya: Panduan Berkomunikasi Dengan Orang-Orang Berbeda Budaya, Bandung: PT. Remaja Rosdakarya, 2005.

Mulyana, Deddy. IImu Komunikasi Suatu Pengantar, Bandung: PT Remaja Rosdakarya, 2014.

Pungin Burhan, "Sosiologi Komunikasi:

Teori Paradigma Dan Diskursus 
Komunike, Volume XI, No. 2, Desember 2019

Teknologi Komunikasi Di

Masyarakat", Jakarta: PT. Kencana

Prenada Media Group, 2007.

Ristiana Kadarsih, "Teori Penetrasi Sosial

dan Hubungan Interpersonal",

Jurnal Dakwah, Vol. X, Nomor 1,

Januari-Juni 2009.

Zuriah, Nurul. Metode Penelitian Sosial

Dan Pendidikan, Jakarta: PT Bumi

Aksara, 2009. 